УДК $551.21+550.34$

\title{
ИЗВЕРЖЕНИЯ ГРЯЗЕВЫХ ВУЛКАНОВ АЗЕРБАЙДЖАНА И ИХ КОРРЕЛЯЦИЯ С СИЛЬНЫМИ ЗЕМЛЕТРЯСЕНИЯМИ
}

\author{
Г. В. Устюгов, В. В. Ершов \\ Институт морской геологии и геофизики ДВО РАН, г. Южно-Сахалинск \\ Поступила в редакцию 14 августа 2019 г.
}

\begin{abstract}
Аннотация: обсуждаются закономерности извержений грязевых вулканов Азербайджана за последние два столетия. Среднегодовое количество извержений остается примерно постоянным с 1946 г. и составляет около 3,7 событий в год. Сделана оченка полноты каталога извержений, которая по нашим расчетам составляет примерно 53 \%. Максимумы и минимумы грязевулканической активности повторяются через определенные промежутки времени. По первым оченкам длительность этих ииклов составляет 15-20 лет. Проанализирована частота извержений грязевых вулканов. Установлено, что повторные извержения происходят, как правило, спустя относительно небольшой интервал времени: в течение четырех лет происходят около $28 \%$, а в течение десяти лет - около 52 \% извержений. Выполнен поиск возможных корреляций с сильными сейсмическими событиями. Показано, что землетрясения могут выступать триггером для грязевулканических извержений. Определены потенциально возможные случаи отклика грязевых вулканов Азербайджана на землетрясения. Однако извержения наблюдались только для небольшой доли этих случаев. В то же время высокой активности грязевых вулканов не всегда предшествовали какие-либо сильные землетрясения.
\end{abstract}

Ключевые слова: грязевые вулканы, эруптивная деятельность, периодичность извержений, сейсмичность, триггерное землетрясение, Азербайджан.

\section{ERUPTIONS OF MUD VOLCANOES IN AZERBAIJAN AND THEIR CORRELATION WITH STRONG EARTHQUAKES}

\author{
G. V. Ustyugov, V. V. Ershov \\ Institute of Marine Geology and Geophysics, Far East Branch, RAS, Yuzhno-Sakhalinsk \\ Received 14 August 2019
}

\begin{abstract}
Azerbaijan over the recent two centuries are discussed. The average annual number of eruptions has remained approximately constant since 1946 and amounts to about 3.7 events per year. An assessment of the completeness of the eruption catalog is made, which, according to our calculations, is about 53\%. The maximums and minimums of mud volcanic activity are repeated after certain time periods. According to the first estimates, the duration of these cycles is 15-20 years. The frequency of mud volcanic eruptions was analyzed. It is established that repeated eruptions usually occur after a relatively short time interval: within four years about $28 \%$, and within ten years about $52 \%$ of eruptions. The correlations between eruptions and strong seismic events were analyzed. It is shown that earthquakes can be a trigger for mud volcanic eruptions. Potentially possible cases of response of mud volcanoes of Azerbaijan to earthquakes was identified. However, eruptions were observed only for a small percentage of these cases. At the same time, high activity of mud volcanoes was not always preceded by any strong earthquakes.
\end{abstract}

Key words: mud volcanoes, eruptive activity, periodicity of eruptions, seismicity, triggering earthquake, Azerbaijan. 


\section{Введение}

Грязевые вулканы - это природные флюидодинамические системы, в которых происходит интенсивный перенос энергии и вещества из недр Земли на ее поверхность. Грязевой вулканизм - это геологическое явление планетарного масштаба. Грязевые вулканы редко бывают одиночными, чаще они группируются в наземные или подводные провинции. Большинство грязевулканических провинций тяготеет к альпийской зоне складчатости. Проявления грязевого вулканизма в основном встречаются в предгорных и межгорных впадинах, в которых накапливаются мощные (10-20 км) толщи терригенно-глинистых кайнозойских отложений [1].

Деятельность грязевых вулканов обычно распадается на два этапа. На этапе извержения происходят выбросы больших объемов грязевулканической брекчии, которая изливается в виде мощных веерообразных или языкообразных потоков шириной в несколько сот метров и длиной более километра. На более длительном этапе грифонной деятельности происходит относительно спокойное выделение в небольшом количестве продуктов грязевого вулканизма через систему грифонов на теле вулкана.

Грязевые вулканы - носители огромной познавательной информации о недрах Земли. Их изучение связано с решением различных проблемных теоретических и практических вопросов геологии, геохимии, геофизики: связь с сейсмичностью и нефтегазоносностью земных недр, геологическая эмиссия парниковых газов и др. Грязевой вулканизм относится к опасным природным явлениям, которые должны учитываться при проектировании и эксплуатации инженерных сооружений. В связи с этим важно иметь корректные количественные оценки пространственно-временных масштабов деятельности грязевых вулканов. В настоящее время большинство исследователей считают, что усиление грязевулканической активности может происходить под влиянием сильных сейсмических событий. Поэтому важно знать степень влияния землетрясений на динамику извержений грязевых вулканов.

Азербайджан является классической грязевулканической провинцией. По количеству грязевых вулканов, их разнообразию и очень активной деятельности этот регион не имеет себе равных в мире. Здесь расположено свыше 350 грязевых вулканов, из которых около 150 - морские [2]. Извержения азербайджанских грязевых вулканов регулярно фиксируются, а соответствующие данные систематизируются в каталоги, которые время от времени обновляются. Это дает исследователям большую выборку данных для изучения различных аспектов грязевулканической деятельности. Целью данной работы является анализ динамики извержений грязевых вулканов Азербайджана и их связи с сильными региональными землетрясениями.

Объект и методы исследования

Южно-Каспийский нефтегазоносный бассейн, охватывающий территории Восточного Азербайджа- на, Юго-Западного Туркменистана и акваторию Южного Каспия, представляет собой область крупного прогибания с мощной (до 30 км) осадочной толщей и широким развитием грязевого вулканизма [2]. Однако наибольшее количество грязевых вулканов, причем, более крупных и часто извергающихся, расположено именно в восточной части Азербайджана и прилегающей акватории Каспийского моря. В этом регионе встречаются все формы проявления грязевого вулканизма - действующие, потухшие, погребенные, подводные, островные, нефтевыделяющие.

Почти все проявления грязевого вулканизма в Азербайджане связаны с нефтегазоносными структурами. Здесь выделяют шесть нефтегазоносных районов, в пределах которых располагаются грязевые вулканы: Прикаспийско-Губинский, Шамахы-Гобустанский, Абшеронский, Нижнекуринский, Бакинский архипелаг, глубоководная часть Южного Каспия (рис. 1). Наибольшее количество грязевых вулканов сосредоточено в Шамахы-Гобустанском районе около 120 вулканов [2]. Количество грязевых вулканов в акватории Южного Каспия достоверно неизвестно. В морских условиях (особенно там, где глубины достигают 700-900 м) трудно установить их количество и истинные размеры. Проведенными в Южно-Каспийской впадине аэромагнитными, геоакустическими, сейсморазведочными, морфометрическими и геохимическими исследованиями выявлено более 150 грязевых вулканов, из которых 32 расположены в глубоководной части Южного Каспия. Наиболее крупные вулканы расположены в юго-западной части Южного Каспия [3, 4]. При общем фоне глубины моря 500-900 м их высота изменяется от 10 до 250 м, а наибольший диаметр основания составляет около 10 км. Извержения морских грязевых вулканов на шельфе могут образовывать острова и банки. В пределах Бакинского архипелага известны восемь островов грязевулканического происхождения (Зенбил, Гил, Харе-Зиря, Гарасу, Сенги-Муган и др.). Из всего множества азербайджанских грязевых вулканов можно выделить восемь наиболее активных вулканов, которые извергались 10 и более раз за последние два столетия: Шихзарли, Гушчу, Торагай, Аязахатарма (Шамахы-Гобустанский район); Локбатан, Кейреки (Абшеронский район); о-в Харе-Зиря, о-в Гил (Бакинский архипелаг).

В образовании брекчии азербайджанских грязевых вулканов принимают участие породы всего разреза четвертичных, третичных и верхнемеловых отложений. Однако отложения олигоцен-миоценового возраста (главным образом, майкопская свита) составляют наибольший процент в грязевулканических выбросах [5]. Вариации возраста пород-выбросов в широком интервале от мелового до плиоценового сильно затрудняют определение стратиграфической и глубинной приуроченности очагов грязевого вулканизма. Данную проблему обычно решают на основе изотопно-геохимических исследований флюидов, выделяемых грязевыми вулканами. В работе [6] показано, 


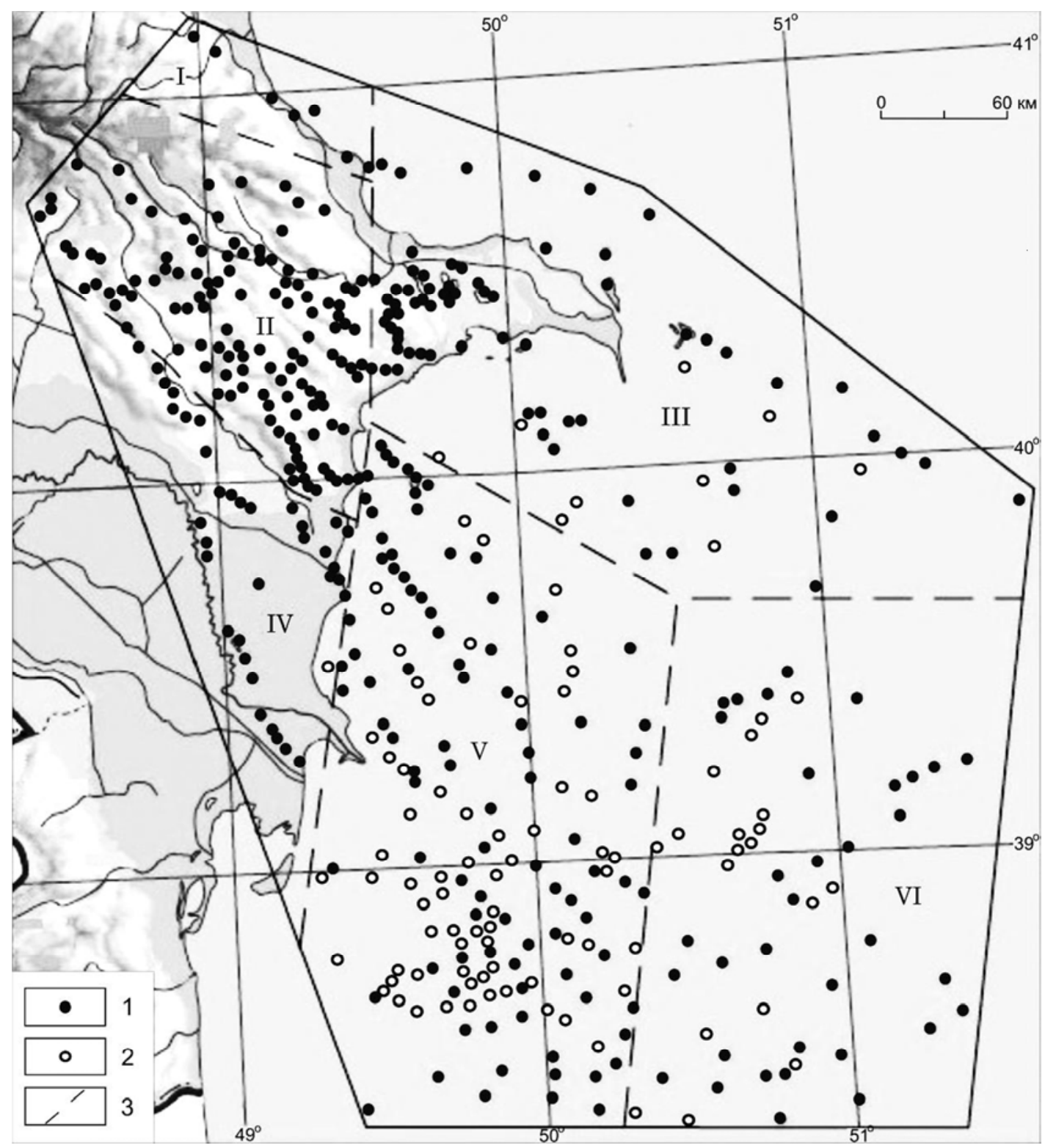

Puc. 1. Пространственное распределение грязевых вулканов Азербайджана [2]. Грязевые вулканы: 1 - установленные, 2 предполагаемые; 3 - границы нефтегазоносных районов и перспективных зон складчатости: $I$ - Прикаспийско-Губинский, II - Шамахы-Гобустанский, $I I I$ - Абшеронский, $I V$ - Нижнекуринский, $V$ - Бакинский архипелаг, $V I$ - глубоководная часть Южного Каспия.

что около 50 \% азербайджанских грязевых вулканов выделяют палеоген-нижнемиоценовые нефти. Исходя из уровня катагенетической зрелости углеводородных газов, корни грязевых вулканов Азербайджана расположены в основном на глубинах от 6 до 12 км. Эти глубины в северной и северо-западной бортовых частях Южно-Каспийского бассейна соответствуют юрско-меловому комплексу отложений. В центральной более погруженной части бассейна эти глубины соответствуют палеоген-миоценовому комплексу отложений.

Для грязевых вулканов Азербайджана существует довольно подробный каталог извержений, зафиксированных с 1810 по 2014 гг. [2], который в процессе данной работы был дополнен нами по 2018 г. более свежими данными из работы [7]. Каталог включает в себя сведения о более 400 извержениях, которые произошли на 94 наземных и морских вулканах.

Отметим, что точное количество всех зафиксированных с 1810 по 2018 гг. грязевулканических извержений в Азербайджане насчитывает 419 событий. Однако имеется 14 случаев, когда на одном и том же вулкане в течение одного и того же календарного года происходило два извержения. Трудно представить, что грязевой вулкан в течение нескольких месяцев (или тем более дней) мог бы успеть накопить большое количество энергии и вещества, которое необходимо для следующего извержения. Поэтому мы полагаем, что в этих случаях имеем дело не с двумя отдельными извержениями, а с одним длительным двухактным извержением. Первый выброс не реализует весь накопленный эруптивный потенциал, в связи с чем 
через некоторое непродолжительное время следует второй выброс. Кроме того, даты многих извержений в каталоге содержат только год события без указания числа и месяца. Следовательно, фактическая дискретность наблюдений (и соответственно каталога) составляет один год, меньшие промежутки времени при анализе каталога рассматривать некорректно. Поэтому при дальнейшем анализе в нашей работе мы считаем, что количество извержений грязевых вулканов Азербайджана, зарегистрированных за указанный период наблюдений, составляет 405 событий.

Для анализа сейсмичности Азербайджана и сопредельных территорий нами использовался унифицированный каталог землетрясений, используемый для задач общего сейсмического районирования территории Российской Федерации [8]. Каталог содержит данные о землетрясениях с древнейших времен по 2013 г. Представительная магнитуда каталога за последнее столетие составляет около 4,0.

\section{Результаты исследования и их обсуждение}

1. Извержения грязевых вулканов Азербайджана

В качестве первичного анализа эруптивной деятельности грязевых вулканов Азербайджана был построен график ежегодного числа извержений в период с 1810 по 2018 гг. (рис. 2). Хорошо видно, что интенсивность извержений распределена неравномерно в разные промежутки времени и неуклонно увеличивается к концу периода наблюдений. Поэтому весь период наблюдений можно разделить на четыре промежутка времени, в каждом из которых интенсивность извержений примерно одинакова. Среднегодовое количество извержений грязевых вулканов за 1810-1846 гг. и 1846-1900 гг. составляет примерно 0,3 и 0,8 соответственно. Уже с 1900 до 1946 гг. среднее количество извержений увеличилось примерно вдвое и составило 1,9 событий в год. С 1946 г. и по настоящее время среднее количество извержений остается примерно постоянным и составляет 3,7 событий в год.
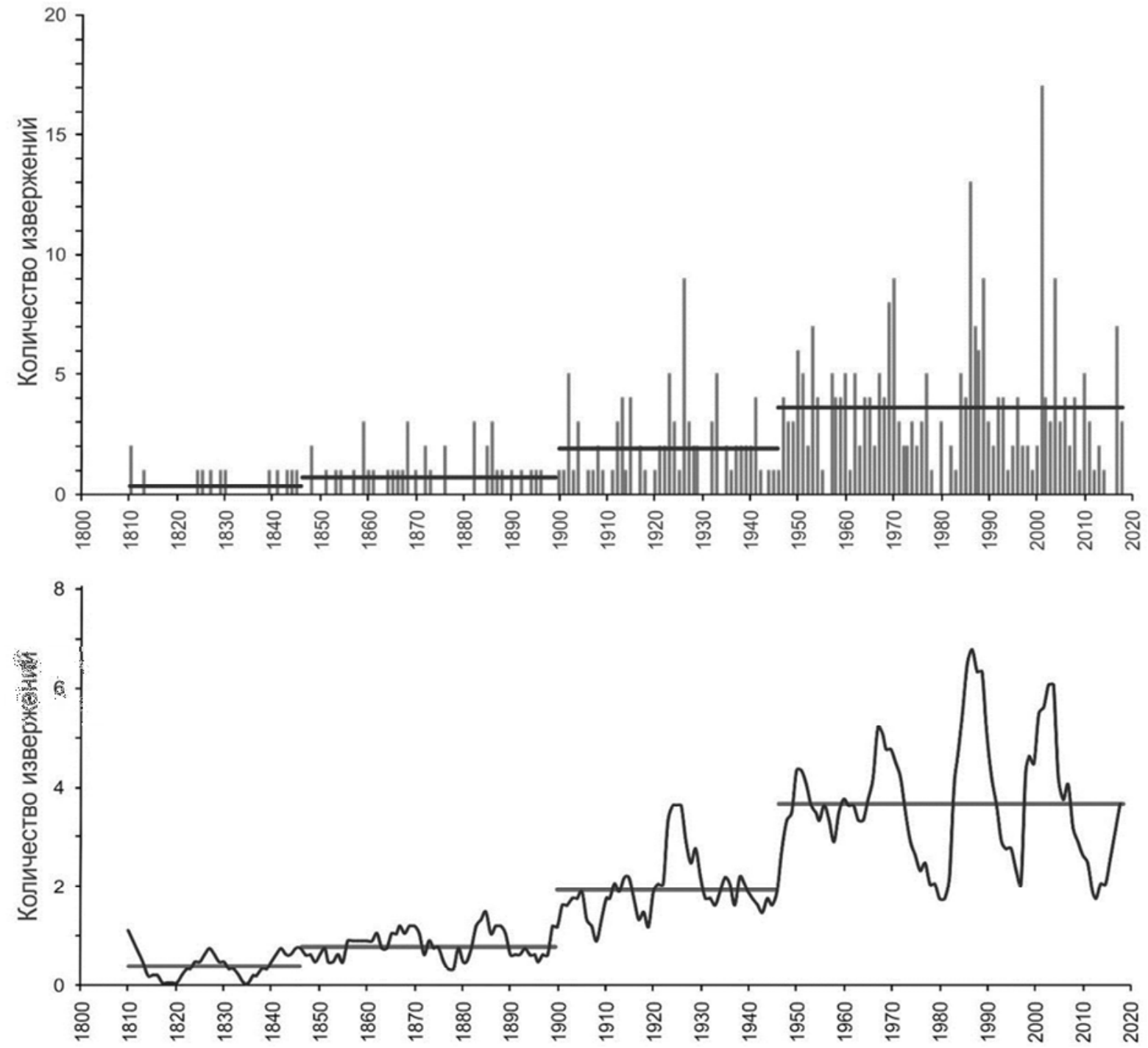

Puc. 2. Распределение во времени извержений грязевых вулканов Азербайджана, зарегистрированных с 1810 по 2018 гг., с указанием среднего числа извержений в разные промежутки времени. На верхнем рисунке - ежегодное число извержений по эмпирическим данным из каталога. На нижнем рисунке - скользящее среднее, построенное по этим данным. 
Рассматриваемый период наблюдений - около 200 лет - можно считать ничтожно малым в геологических масштабах времени. Заметим, что согласно работам [4, 9] деятельность грязевых вулканов началась в среднем и позднем плиоцене, т.е. 2,4-3,5 млн лет назад. Поэтому трудно представить, что за последние 200 лет мог бы произойти столь ощутимый и последовательный рост грязевулканической активности. Более правдоподобно считать, что рост интенсивности зафиксированных извержений является следствием совершенствования системы наблюдений за грязевыми вулканами. Очевидно, что данные каталога извержений за более ранние промежутки времени содержат много пропусков, т.е. незафиксированных извержений. Отсюда встает актуальная задача по определению полноты каталога извержений грязевых вулканов Азербайджана.

В работе [10] исходят из предположения, что время извержений равномерно распределено в течение суток и очень малое число извержений, которые произошли ночью, обусловлено только их пропусками. Тогда полнота каталога извержений Азербайджана с 1965 по 2001 гг. составляет около 75 \%. Вывод сделан на основе анализа данных о 25 извержениях (начиная с 1965 г.), для которых зарегистрировано точное время извержения. Полнота каталога с 1810 по 2001 гг. оценивается в работе [10] от 37 до $71 \%$. При этом для вулканов (таких как Локбатан или Кейреки), которые находятся вблизи густонаселенных районов, записи об извержениях, вероятно, могут считаться достаточно полными и точными.

Нами для оценки полноты каталога извержений грязевых вулканов Азербайджана использовался следующий подход. Мы исходили из предположения, что, начиная с 1946 г., извержения грязевых вулканов регистрируются практически без пропусков. Будем полагать, что истинное среднегодовое количество извержений с 1810 г. до 1946 г. также должно составлять примерно 3,7 событий, т.е. как и после 1946 г. Тогда количество извержений азербайджанских грязевых вулканов с 1810 по 2018 гг. составит около 770 событий, что почти в 2 раза больше, чем зафиксировано на сегодняшний день. Следовательно, полнота каталога извержений составляет по нашим оценкам около $53 \%$. Безусловно, такая существенная нехватка данных является серьезным препятствием для понимания закономерностей пароксизмальной деятельности грязевых вулканов Азербайджана. Поэтому многие выводы следует рассматривать в качестве рабочих гипотез, полагая, однако, что четкие и устойчивые тенденции будут просматриваться и в неполном наборе данных.

Временной график количества извержений имеет резкие колебания. Для сглаживания таких скачков и выявления имеющихся тенденций в развитии процесса нами использовался метод скользящего среднего. Весовые коэффициенты, используемые для построения полиномиального тренда в окне усреднения, приведены в работе [11]. Порядок полинома в окне был выбран равным единице, длина окна составила семь лет. На скользящем среднем хорошо видно, что интенсивность извержений имеет циклический характер - максимумы и минимумы интенсивности повторяются через определенные интервалы времени (рис. 2). Длительность этих циклов - по данным наблюдений с 1946 г. - составляет 15-20 лет. В работе [12] охарактеризована периодичность магматизма разных масштабов с разными причинами и следствиями. Из этой работы следует, что короткопериодные вариации вулканизма могут быть связаны с периодами солнечной активности. Более подробный анализ периодических вариаций грязевулканических извержений требует дополнительных исследований.

Интересен также вопрос об индивидуальной периодичности извержений, т.е. об интервалах времени между следующими друг за другом извержениями отдельно взятого вулкана. Для понимания читателем дальнейших расчетов необходимо отметить следующее. Количество зарегистрированных извержений и количество наблюдаемых интервалов времени между извержениями не будут равны друг другу. Для расчета одного интервала времени требуется два извержения, для расчета двух интервалов - три извержения и т.д. Кроме того, для 31 грязевого вулкана зарегистрировано только по одному извержению. Таким образом, по данным дополненного каталога извержений грязевых вулканов Азербайджана мы получили 311 интервалов времени между двумя хронологически последовательными извержениями каждого вулкана. Эти интервалы времени значительно варьируют, но в целом с ростом наблюдаемого периода извержений происходит быстрое уменьшение числа извержений с данным периодом. В течение первых 10 лет происходит около $52 \%$ извержений (рис. 3). При этом пропуски извержений, о которых говорилось выше, скорее всего, удлиняют интервалы времени между извержениями и увеличивают тем самым долю долгопериодных извержений. Другими словами, спад количества извержений с ростом периода этих извержений должен быть еще более крутым. Если посмотреть более детально область малых периодов извержений, то становится видно, что тенденция уменьшения долгопериодных извержений сохраняется и на других масштабах времени (рис. 4). В более четверти всех зафиксированных случаев последующее извержение грязевого вулкана происходит в течение четырех лет после предыдущего. Этот важный вывод будет использован нами далее - в следующей части статьи.

\section{2. Корреляция грязевулканической активности с землетрясениями}

Один из традиционных аспектов исследования грязевого вулканизма - анализ связи между различными параметрами грязевулканической деятельности и сейсмичностью. Этот вопрос рассматривается исследователями из разных стран, начиная с середины XIX века. Анализ публикаций по данной теме свидетельствует о наличии связи между усилением активности грязевых вулканов и сейсмическими событиями [10, 13-18]. 


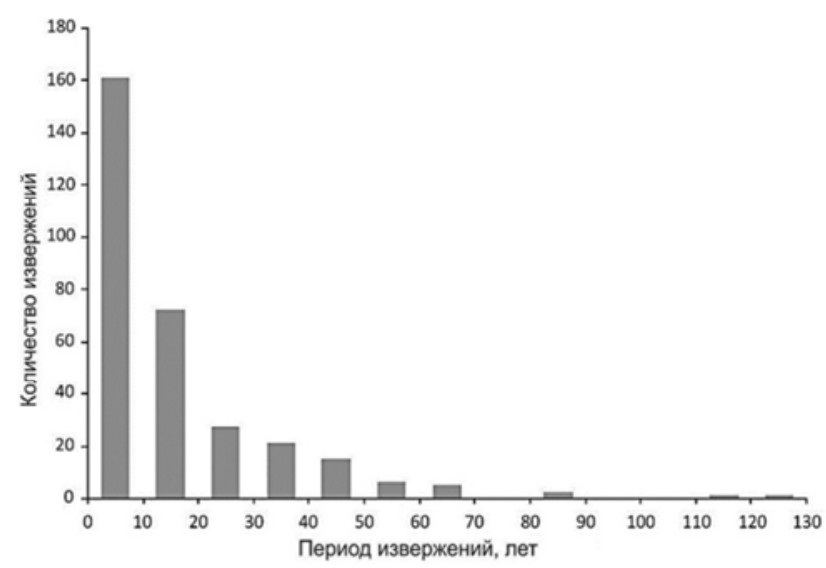

Puc. 3. Периодичность извержений грязевых вулканов Азербайджана (шаг разбиения гистограммы 10 лет).

Считается, что землетрясения могут выступать спусковым механизмом - триггером - для грязевулканических извержений. Следовательно, в течение некоторого времени после землетрясений можно ожидать прирост количества извержений грязевых вулканов. В работе [10] показано, что число пар событий «землетрясение-извержение» статистически значимо выше, чем это было бы при случайных совпадениях. Однако дальше мы сталкиваемся с рядом серьезных проблем. Тот факт, что некоторые грязевые вулканы в каких-то случаях реагируют на землетрясения, сам по себе нам мало что говорит. Он рождает много новых вопросов, остающихся пока без ответа. Каков механизм триггерного воздействия землетрясений на грязевые вулканы? Какие из землетрясений могут быть триггерами для грязевых вулканов? Какая доля вулканов откликнется на триггерное землетрясение? Какой является длительность отклика грязевых вулканов на триггерное землетрясение?

Большинство исследователей приходят к мнению, что доминирующее влияние на грязевулканическую деятельность оказывают динамические, а не статические, напряжения от землетрясений. Динамические напряжения медленнее уменьшаются с расстоянием по сравнению со статическими. Это делает динамические напряжения более эффективным спусковым механизмом на больших расстояниях. Доказательства корреляции между статическими изменениями напряжений и грязевулканическими извержениями в большинстве случаев отсутствуют $[15,19]$. В работе [20] говорится о существовании частотной зависимости отклика грязевых вулканов на землетрясения длиннопериодные сейсмические волны более эффективны как триггеры, чем волны с меньшим периодом той же самой амплитуды. В то же время в работе [18] основным фактором является пиковая амплитуда динамических напряжений. Согласно работе [15] возможны следующие механизмы усиления грязевулканической активности от землетрясений: разжижение и потеря прочности грунтов, возникновение избыточного порового давления, повышение гидравлической проницаемости из-за удаления гидравлических барье-

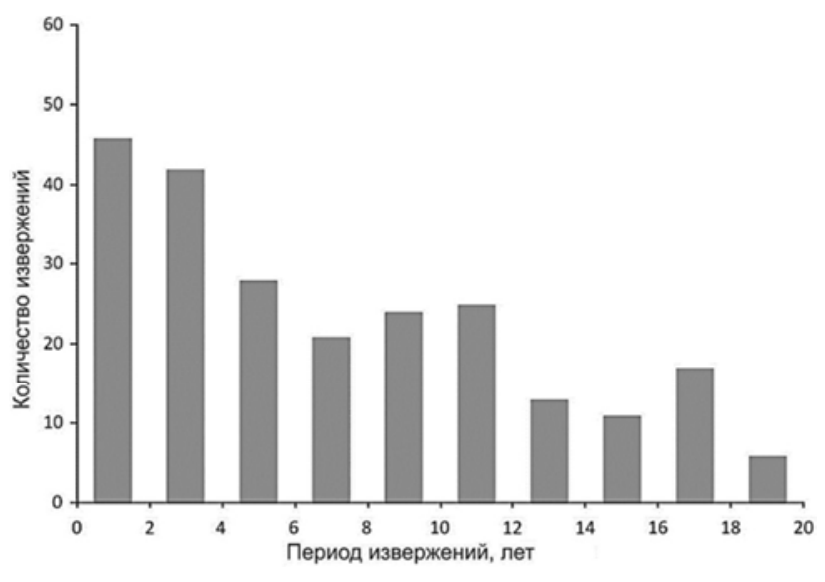

Puc. 4. Периодичность извержений грязевых вулканов Азербайджана (шаг разбиения гистограммы два года).

ров, зарождение и рост большого количества газовых пузырьков. Эти механизмы не являются взаимоисключающими и могут действовать одновременно.

В работе [10] говорится, что корреляция между землетрясениями и извержениями наиболее заметна на расстоянии до 100 км. При этом триггерами наиболее часто являются землетрясения, которые генерируют в месте нахождения грязевого вулкана сейсмические интенсивности выше 5-6 баллов по шкале Меркалли. Однако при достаточно высокой сейсмической интенсивности извергается лишь часть грязевых вулканов. В работе [2] говорится, что причинноследственная связь усиления грязевулканической активности с землетрясениями хорошо прослеживается, когда очаг землетрясения и грязевой вулкан находятся в пределах одной разломной структуры, а вулкан накопил достаточное количество вещества и энергии для извержения. Заметим, что сами извержения сильно различаются между собой: от спокойных и относительно небольших непрерывных излияний до сильных взрывных выбросов в единицы и десятки тысяч кубометров брекчии. Отклик вулканов на землетрясения может происходить не только в формате извержений. Этот отклик может ограничиться изменениями дебита свободных газов, элементного состава и температуры водогрязевой смеси в грифонах вулкана $[13,14]$.

Существуют и количественные подходы к оценке пороговых значениях сейсмического воздействия. В работах $[15,21]$ рассматривается триггерное воздействия землетрясений на флюидные системы, в том числе и на грязевые вулканы. Получена эмпирическая формула $\log \mathrm{R}_{\max }=2,05( \pm 0,10)+0,45 \mathrm{M}$, где $\mathrm{M}$ - магнитуда землетрясения, $\mathrm{R}_{\max }$ - максимальное эпицентральное расстояние от очага землетрясения до флюидной системы, на котором возможен триггерный эффект. Другими словами, с помощью этой формулы определяется возможность флюидодинамических проявлений землетрясения. Мы использовали эту формулу, чтобы определить случаи потенциально возможных извержений грязевых вулканов Азербайджана, спровоцированных триггерными землетрясениями (рис. 5). 


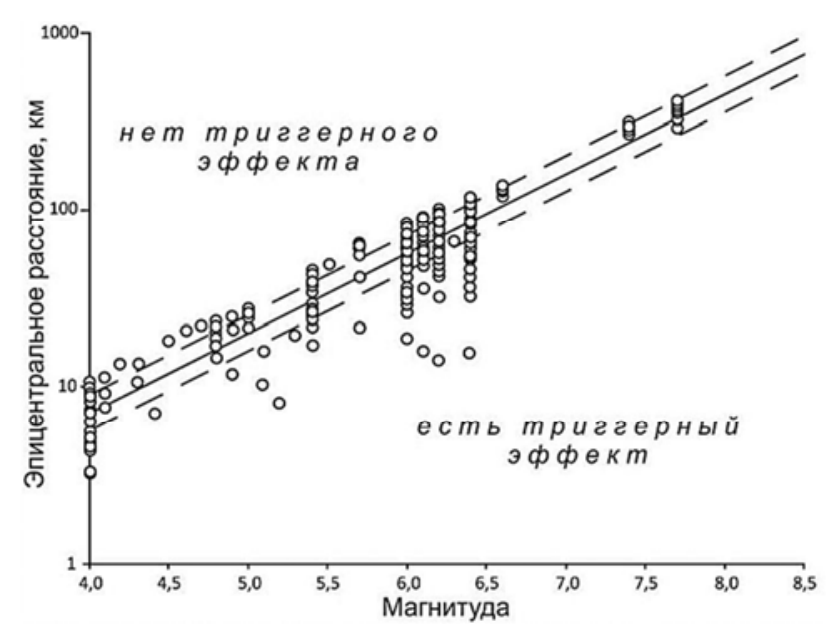

Puc. 5. Случаи потенциально возможной активизации грязевых вулканов Азербайджана, обусловленной землетрясениями-триггерами.

Прямая линия, соответствующая указанной формуле, делит плоскость диаграммы на две области. Триггерный эффект возможен в тех случаях, когда фигуративные точки находятся ниже (или вблизи) этой линии-границы. Используя указанную формулу, можно выделить ряд землетрясений, которые должны были бы спровоцировать большое количество извержений грязевых вулканов: 1859 г. $(\mathrm{M}=6,1), 1872$ г. $(M=6,0), 1895$ г. $(M=7,7), 1902$ г. $(M=6,2), 1911$ г. $(\mathrm{M}=6,4), 1963$ г. $(\mathrm{M}=6,2), 2000$ г. $(\mathrm{M}=6,4)$. Но только в случае с землетрясением в ноябре 2000 г. наблюдался четко выраженный отклик грязевых вулканов. Действительно, в 2001 г. зафиксировано рекордно высокое для Азербайджана количество извержений грязевых вулканов (17 событий). Но в остальных случаях, когда землетрясения подходили по своим параметрам в роли «спускового механизма», отреагировала только очень небольшая часть грязевых вулканов. Отметим также, что есть и другие локальные максимумы активности грязевых вулканов (1926, 1970, 1986, 1989, 2004 гг.), когда было зафиксировано девять и более грязевулканических извержений. Однако этим максимумам не предшествовали какие-либо сильные землетрясения, которые могли бы сыграть роль триггера. Следовательно, помимо землетрясений есть и другие факторы, которые играют важную роль в процессах активизации грязевых вулканов.

Пожалуй, наиболее сложный вопрос - это возможный интервал времени между землетрясением и запущенным им грязевулканическим извержением. Известны случаи, когда извержения возникают в течение нескольких минут после сильной тряски, вызванной прохождением сейсмических волн от землетрясений. Так, после произошедшего 13 февраля 1902 г. Шамахинского землетрясения (магнитуда 6,2) в тот же день изверглись грязевые вулканы Шихзарли и Бозаахтарма [2]. Известны также примеры, когда усиление грязевулканической активности происходит спустя длительное время после землетрясений - от нескольких месяцев до двух-трех лет. После земле- трясения 25 ноября 2000 г. с магнитудой 6,4 наибольшее количество извержений произошло в течение двух лет после землетрясений, а самая высокая частота наблюдалась в течение первых шести месяцев [17]. При этом в работе [17] склонны считать, что время отклика грязевых вулканов Азербайджана может достигать пяти лет. Мы не можем с этим согласиться, поскольку выше нами было показано, что значительная часть грязевых вулканов извергается в течение четырех лет после предыдущего извержения. Другими словами, за четыре года вулканы успевают извергнуться в силу естественной динамики грязевулканических процессов - независимо от землетрясений.

\section{Заключение}

В ходе проведенного исследования установлены закономерности извержений грязевых вулканов Азербайджана и их связи с региональной сейсмичностью. Среднегодовое количество извержений азербайджанских грязевых вулканов остается примерно постоянным с 1946 г. и составляет около 3,7 событий в год. До 1946 г. среднегодовое количество извержений значительно меньше, что, вероятно, обусловлено пропусками извержений из-за несовершенства системы наблюдений за грязевыми вулканами. По нашим оценкам полный каталог извержений должен был бы насчитывать около 770 событий, т.е. полнота имеющегося каталога извержений составляет около $53 \%$. Интенсивность извержений в течение двухсотлетнего периода наблюдений имеет циклический характер максимумы и минимумы грязевулканической активности характеризуются регулярной повторяемостью во времени. Длительность этих циклов по первым беглым оценкам составляет 15-20 лет. Интервалы времени между двумя хронологически последовательными извержениями каждого отдельно взятого вулкана варьируют в широком диапазоне. Однако в целом наблюдается четкая тенденция быстрого снижения количества извержений с ростом интервала времени между извержениями. В течение первых четырех лет после предыдущего извержения происходит около $28 \%$ последующих извержений грязевых вулканов Азербайджана, а в течение первых 10 лет около $52 \%$.

Землетрясения - с учетом магнитуды и эпицентрального расстояния до вулкана - могут играть роль спускового механизма для грязевулканических извержений. Триггерами наиболее часто являются землетрясения, происходящие в пределах 100 км, которые генерируют в месте нахождения грязевого вулкана сейсмические интенсивности 5-6 баллов и выше по шкале Меркалли. Интервал времени между землетрясением и запущенным им грязевулканическим извержением варьирует от нескольких минут до 2-3 лет. В то же время влияние землетрясений на эруптивную деятельность грязевых вулканов нельзя считать доминирующим. На примере Азербайджана показано, что есть немало случаев, когда после землетрясений, подходящих на роль триггеров, извергалась только 
незначительная часть грязевых вулканов. И наоборот, периодам максимальной активности азербайджанских грязевых вулканов зачастую не предшествовали какие-либо сильные землетрясения. С одной стороны, это говорит о том, что есть и другие факторы, играющие более важную роль в динамике извержений грязевых вулканов. С другой стороны, это говорит о недостаточной изученности данного вопроса и необходимости дополнительных исследований в этом направлении. Вероятно, необходимо учитывать также, что грязевой вулкан должен накопить определенное количество вещества и энергии, которое минимально необходимо для его активизации в ответ на землетрясение.

\section{ЛИТЕРАТУРА}

1. Холодов, В. Н. Грязевые вулканы: распространение и генезис / В. Н. Холодов // Геология и полезные ископаемые Мирового океана. - 2012. - № 4. - С. 5-27.

2. Атлас грязевых вулканов мира / Ад. А. Алиев [и др.]. Баку: Nafta-Press, 2015. - 322 c.

3. Davies, $R$. J. Emplacement of giant mud volcanoes in the South Caspian Basin: 3D seismic reflection imaging of their root zones / R. J. Davies, S. A. Stewart // Journal of the Geological Society. - 2005. - Vol. 162. - P. 1-4.

4. Yusifov, M. Classification of mud volcanoes in the South Caspian Basin, offshore Azerbaijan / M. Yusifov, P. D. Rabinowitz // Marine and Petroleum Geology. - 2004. - Vol. 21. P. 965-975.

5. Байрамов, A. C. Геология Азербайджана. Тектоника, грязевой вулканизм, история геологического развития / А. С. Байрамов, В. А. Горин. - Баку: АН АзССР, 1953. - 259 с.

6. Гулиев, И. С. Геохимические особенности и источники флюидов грязевых вулканов Южно-Каспийского осадочного бассейна в свете новых данных по изотопии $\mathrm{C}, \mathrm{H}$ и О / И. С. Гулиев, Д. А. Гусейнов, А. А. Фейзуллаев // Геохимия. 2004. - № 7. - C. 792-800.

7. Baloglanov, E. E. Mud volcanoes of the world: classifications activities and environmental hazard (informationalanalytical review) / E. E. Baloglanov, O. R. Abbasov, R. V. Akhundov // European Journal of Natural History. - 2018. - № 5. - P. 12-26.

8. Уломов, В. И. Специализированный каталог землетрясений для задач общего сейсмического районирования территории Российской Федерации [Электронный ресурс] / В. И. Уломов, Н. С. Медведева. - Режим доступа: http://seismosu.ifz.ru/documents/Eartquake-Catalog-СК3.pdf (дата обращения 30.07.2019).

ФГБУН Институт морской геологии и геофизики ДВО РАН, г. Южно-Сахалинск

Устюгов Геннадий Викторович, инженер-исследователь E-mail: gen.ustyugov@mail.ru

Тел.: +7 (4242) 791517

Ериов Валерий Валерьевич, кандидат физикоматематических наук, ведущиий научный сотрудник E-mail:valery_ershov@mail.ru

Тел.: +7 (4242) 791517
9. Шнюков, Е. Ф. Грязевой вулканизм Средиземного, Черного и Каспийского морей: специфика развития и проявления / Е. Ф. Шнюков, Ад. А. Алиев, Р. Р. Рахманов // Геология и полезные ископаемые Мирового океана. - 2017. - № 2. - C. 5-25.

10. . Correlations between earthquakes and large mud volcano eruptions / R. Mellors [et al.] // Journal of Geophysical Research. - 2007. - Vol. 112. - doi: 10.1029/2006JB004489.

11. Кендэл, М. Временные ряды / М. Кендэл. - М.: Финансы и статистика, 1981. - $199 \mathrm{c}$.

12. Добрецов, Н. Л. О периодичности и разномасштабных факторах вулканических извержений / Н. Л. Добрецов // Геология и геофизика. - 2015. - № 12. - С. 2107-2117.

13. Проявления Невельского и Горнозаводского землетрясений 2006-2007 гг. в динамике грифонной деятельности Южно-Сахалинского газоводолитокластитового (грязевого) вулкана / В. В. Ершов [и др.] // Доклады Академии наук. 2008. - Т. 423, № 4. - С. 533-537.

14. Вариации параметров грязевулканической деятельности и их связь с сейсмичностью юга острова Сахалин / В. В. Ершов [и др.] // Региональная геология и металлогения. 2010. - № 42. - C. 49-57.

15. Manga, M. Earthquake triggering of mud volcanoes / M. Manga, M. Brumm, M. L. Rudolph // Marine and Petroleum Geology. - 2009. - Vol. 26. - P. 1785-1798.

16. Rudolph, M. L. Mud volcano response to the 4 April $2010 \mathrm{El}$ Mayor-Cucapah earthquake / M. L. Rudolph, M. Manga // Journal of Geophysical Research. - 2010. - Vol. 115. - doi: 10.1029/2010JB007737.

17. Evaluation of earthquake-induced strain in promoting mud eruptions: the case of Shamakhi-Gobustan-Absheron areas, Azerbaijan / G. Babayev [et al.] // Natural Hazards. - 2014. Vol. 72. - P. 789-808.

18. Dynamic triggering of mud volcano eruptions during the 2016-2017 Central Italy seismic sequence: triggering of mud volcano eruptions / D. Maestrelli [et al.] // Journal of Geophysical Research: Solid Earth. - 2017. - Vol. 122. - P. 9149-9165.

19. Bonini, M. Long- and short-term triggering and modulation of mud volcano eruptions by earthquakes / M. Bonini, M. L. Rudolph, M. Manga // Tectonophysics. - 2016. - Vol. 672-673. - P. 190-211.

20. Rudolph, M. L. Frequency dependence of mud volcano response to earthquakes / M. L. Rudolph, M. Manga // Geophysical Research Letters. - 2012. - Vol. 39. doi:10.1029/2012GL052383.

21. Liquefaction limit during earthquakes and underground explosions: implications on ground-motion attenuation / C. Wang [et al.] // Bulletin of the Seismological Society of America. - 2006. - Vol. 96. - P. 355-363.

Institute of Marine Geology and Geophysics, Far East Branch, Russian Academy of Sciences, Yuzhno-Sakhalinsk

Ustyugov G. V., engineer-researcher

E-mail: gen.ustyugov@mail.ru

Tel.: +7 (4242) 791517

Ershov $V . V$., candidate of physical and mathematical sciences, leading researcher

E-mail: valery_ershov@mail.ru

Тел.: +7 (4242) 791517 